ISSN: 2302-8556

E-Jurnal Akuntansi Universitas Udayana

Vol.23.2. Mei (2018): 1332-1360

DOI: https://doi.org/10.24843/EJA.2018.v23.i02.p20

\title{
Pengaruh Financial Distress pada Auditor Switching dengan Reputasi Auditor Sebagai Variabel Moderasi
}

\section{Ni Putu Wulan Puspayanti ${ }^{1}$ I D G Dharma Suputra ${ }^{2}$}

\author{
${ }^{1}$ Fakultas Ekonomi dan Bisnis Universitas Udayana (Unud), Bali, Indonesia \\ email:wulanpy@gmail.com/ Tlp : 08977572991 \\ ${ }^{2}$ Fakultas Ekonomi dan Bisnis Universitas Udayana (Unud), Bali, Indonesia
}

\begin{abstract}
ABSTRAK
Laporan keuangan merupakan sarana yang bisa digunakan oleh entitas untuk mengkomunikasikan keadaan terkait dengan kondisi keuangannya kepada pihak-pihak yang berkepentingan Ada kemungkinan laporan keuangan ini dipengaruhi kepentingan pribadi, sementara pihak ketiga yaitu pihak eksternal selaku pemakai laporan keuangan sangat berkepentingan untuk mendapatkan laporan keuangan yang dapat dipercaya. Penelitian ini bertujuan untuk mengetahui pengaruh reputasi auditor dalam memoderasi pengaruh financial distress pada auditor switching. Populasi penelitian ini adalah perusahaan property \& real estate yang terdaftar di BEI tahun 2012-2016 sebanyak 53 perusahaan. Penentuan sampel menggunakan teknik purposive sampling dengan sampel sebanyak 11 perusahaan. Teknik analisis yang digunakan adalah Moderated Regression Analysis (MRA). Hasil penelitian menunjukkan bahwa financial distress berpengaruh positif terhadap auditor switching. Sedangkan reputasi auditor tidak mampu memoderasi pengaruh financial distress pada auditor switching.
\end{abstract}

Kata kunci: Auditor switching, reputasi auditor, financial distress

\begin{abstract}
The financial statements are a means by which the entity may communicate the circumstances related to its financial condition to interested parties. It is possible that these financial statements are influenced by personal interests, while external parties, as users of financial statements, are very interested in obtaining reliable financial statements. This study aims to determine the influence of the auditor's reputation in moderating the influence of financial distress on the switching auditor. The population of this research is property \& real estate company listed in BEI year 2012-2016 as many as 53 companies. Determination of sample using purposive sampling technique with sample of 11 companies. The analysis technique used is Moderated Regression Analysis (MRA). The results showed that financial distress positively affect the switching auditor. While the reputation of the auditor is not able to moderate the influence of financial distress on the switching auditor
\end{abstract}

Keywords: Auditor switching, auditor reputation, financial distress.

\section{PENDAHULUAN}

Setiap perusahaan yang go public diwajibkan untuk menyampaikan laporan keuangan

yang telah di audit oleh pihak independen setiap tahunnya. Laporan keuangan 
merupakan sarana yang bisa digunakan oleh entitas untuk mengkomunikasikan keadaan terkait dengan kondisi keuangannya kepada pihak-pihak yang berkepentingan, baik yang berasal dari internal entitas maupun eksternal entitas (Kieso, 2007).

Banyak pihak yang berkepentingan terhadap laporan keuangan, maka informasi yang disajikan dalam laporan keuangan harus wajar, dapat di percaya dan tidak menyesatkan bagi pemakainya sehingga kebutuhan masing-masing pihak yang berkepentingan dapat terpenuhi. Pihak yang berkepentingan terhadap laporan keuangan suatu perusahaan diantaranya pemilik perusahaan itu sendiri, kreditur, lembaga keuangan, investor, pemerintah, masyarakat umum dan pihak-pihak lainnya (Nabila,2011). Manajemen dalam perusahaan berkewajiban menyajikan laporan keuangan untuk menunjukkan hasil kinerja mereka kepada pihak-pihak yg membutuhkan. Ada kemungkinan laporan keuangan ini dipengaruhi kepentingan pribadi, sementara pihak ketiga yaitu pihak eksternal selaku pemakai laporan keuangan sangat berkepentingan untuk mendapatkan laporan keuangan yang dapat dipercaya (Widyanti,2015). Maka dari itu, diperlukan adanya prosedur pemeriksaan laporan keuangan yang dilakukan oleh Kantor Akuntan Publik (KAP) tertentu melalui seorang auditor yang independen. (Wea dan Murdiawati, 2015).

Penggunaan jasa auditor dapat memberikan jaminan bahwa laporan keuangan yang disajikan sudah relevan dan reliable, sehingga dapat meningkatkan kepercayaan seluruh pihak yang berkepentingan dengan perusahaan (Singgih dan Bawono,2010). Dalam mempertahankan keandalan suatu laporan keuangan perusahaan dan 
ISSN: 2302-8556

E-Jurnal Akuntansi Universitas Udayana

Vol.23.2. Mei (2018): 1332-1360

independensi auditor maka perusahaan di wajibkan untuk melakukan rotasi auditor (auditor switching). Seregar et al. (2011) juga mengungkapkan bahwa masa perikatan audit antara auditor dan klien yang lama dapat menurunkan independensi auditor yang mana masalah ini dapat diselesaikan dengan dilakukan auditor switching.

Auditor switching adalah pergantian auditor atau KAP yang dilakukan oleh perusahaan (klien) dalam pemberian penugasan audit atas laporan keuangan. Auditor switching bisa terjadi karena ada regulasi atau peraturan yang mewajibkan perusahaan untuk melakukan rotasi KAP (mandatory) dan juga karena keinginan dari perusahaan yang melakukan auditor switching secara sukarela (voluntary) (Wea dan Murdiawati, 2015).

Di Indonesia, pemerintah telah mengatur kewajiban pergantian auditor dalam Peraturan Pemerintah No.20 tahun 2015 tentang Praktik Akuntan Publik yang merupakan pengaturan lebih lanjut dari Undang-Undang No.5 tahun 2011 tentang Akuntan Publik. Terkait pergantian auditor secara wajib tersebut, pasal 11 ayat (1) PP No.20 Tahun 2015 menjelaskan bahwa pemberian jasa audit atas laporan keuangan historis terhadap suatu entitas oleh seorang Akuntan Publik dibatasi paling lama untuk 5 (lima) tahun buku berturut-turut, dan akuntan publik dapat memberikan kembali jasa audit atas informasi keuangan historis terhadap entitas setelah 2 (dua) tahun buku berturut-turut tidak memberikan jasa tersebut (pasal 11 ayat 4). Peraturan Pemerintah no.20 tahun 2015 ini menggantikan Peraturan Menteri Keuangan Republik Indonesia no.17 tahun 2008 tentang Jasa Akuntan Publik yang 
mengatur paling lama untuk enam tahun buku berturut-turut dilakukan oleh KAP yang sama, dan paling lama tiga tahun buku berturut-turut dilakukan oleh akuntan publik yang sama.

Sedangkan pergantian sukarela dilakukan apabila klien mengganti auditornya, ketika tidak ada peraturan yang mewajibkan untuk melakukan pergantian auditor. Terdapat dua kemungkinan apabila pergantian auditor dilakukan secara sukarela, yaitu apabila auditor mengundurkan diri dari penugasan yang diterimanya atau klien mengganti auditor untuk jasa yang diberikan. Bluoin et al. (2007) menyatakan bahwa pergantian KAP yang dilakukan oleh klien bertujuan untuk memperkuat sistem pengawasan.

Banyak faktor penyebab terjadinya auditor switching, salah satunya yaitu financial distress. Agiastuti dan Suputra (2016) juga mengungkapkan bahwa financial distress adalah salah satu faktor yang menyebabkan klien melakukan voluntary auditor switching. Financial distress atau kesulitan keuangan dapat diartikan sebagai ketidakmampuan perusahaan untuk membayar kewajiban keuangannya pada saat jatuh tempo yang menyebabkan kebangkrutan perusahaan (Darsono dan Ashari, 2005). Dimana hal tersebut dapat merugikan pemegang saham, kreditur, manajer dan supplier (Saheli dan Abedini,2009). Hendy (2008:68) juga mengungkapkan bahwa financial distress merupakan kondisi suatu perusahaan yang sedang mengalami kesulitan keuangan dan tidak mampu memenuhi berbagai kewajiban kepada pihak lain seperti kreditur, kewajiban kepada pemegang saham 
ISSN: 2302-8556

E-Jurnal Akuntansi Universitas Udayana

Vol.23.2. Mei (2018): 1332-1360

atau obligasi. Hal ini menggambarkan bahwa perusahaan telah mengalami kegagalan dari sudut pandang ekonomi (Gholizadeh,2011). Perusahaan-perusahaan yang mengalami kesulitan keuangan (financial distress) menghadapi ketidakpastian dalam bisnisnya, sehingga menimbulkan kondisi yang mengakibatkan perpindahan KAP sebagaimana halnya diungkapkan oleh Sinarwati (2010) dalam penelitiannya mengungkapkan bahwa ada pengaruh positif antara financial distress dengan pergantian auditor (auditor switching). Hasil penelitian ini bertentangan dengan penelitian yang dilakukan oleh Susan dan Estralita (2011), Pratitis (2011), Khasharmeh (2015) serta Pradnyana dan Suputra (2015) yang menemukan bahwa variabel financial distress tidak memiliki pengaruh terhadap pergantian KAP dalam suatu perusahaan.

Reputasi auditor merupakan prestasi dan kepercayaan publik yang disandang auditor atas nama besar yang dimiliki auditor tersebut. Reputasi KAP merupakan salah satu proksi kualitas audit. Investor akan lebih cenderung pada data akuntansi yang dihasilkan dari auditor yang bereputasi ( Praptitorini dan Januarti, 2007).

Schwartz dan Soo (1995) menyatakan bahwa perusahaan yang bangkrut lebih sering berpindah auditor daripada perusahaan yang tidak bangkrut. Dengan mengganti auditornya dengan auditor yang lebih memiliki nama maka reputasi perusahaan juga akan terangkat di mata investor. KAP yang berafiliasi dengan The Big Four dianggap lebih memiliki kualitas yang tinggi dibandingkan dengan KAP non Big Four. Perusahaan akan lebih memilih KAP Big Four karena dipandang lebih 
meningkatkan kredibilitas perusahaan (Agiastuti dan Suputra, 2016). KAP berafiliasi dengan Big 4 mempunyai kecakapan dan integritas yang tinggi serta mempunyai pengalaman lebih banyak karena mempunyai jumlah dan ragam klien yang lebih banyak sehingga akan menghasilkan kualitas audit yang lebih baik (Arestantya,2016). Menurut Sinarwati (2010) Investor sebagai pihak eksternal melihat informasi akuntansi yang dihasilkan oleh manajemen perusahaan cenderung lebih mempercayai yang dihasilkan oleh auditor yang telah memiliki reputasi yang baik. Namun penelitian Anggreini dan Kuswanto (2012) dan Putra (2015) mengungkapkan reputasi auditor tidak berpengaruh terhadap pergantian kantor akuntan publik (KAP).

Perbedaan dari hasil penelitian diatas memberikan motivasi peneliti untuk meneliti kembali mengenai Pengaruh Financial distress pada Auditor switching dengan Reputasi Auditor sebagai Variabel Moderasi. Penelitian ini mencoba untuk mengetahui adanya hubungan reputasi auditor pada auditor switching yang menyebabkan reputasi auditor dapat memoderasi (memperkuat atau memperlemah) pengaruh financial distress pada auditor switching. Nilai tambah dari penelitian ini adalah menggunakan perusahaan yang terdaftar di Bursa Efek Indonesia (BEI) pada sektor property dan real estate. Pada penelitian terdahulu kebanyakan melakukan penelitian pada sektor manufaktur, serta dikarenakan sektor ini merupakan kebutuhan primer dan sektor ini terus berkembang sampai pada masa ini dan sektor ini diperkirakan akan mampu bertahan pada tahun-tahun mendatang. 
ISSN: 2302-8556

E-Jurnal Akuntansi Universitas Udayana

Vol.23.2. Mei (2018): 1332-1360

Jensen dan Meckling (1976) mendefinisikan teori keagenan sebagai hubungan antara satu orang atau lebih (principal) dengan orang lain (agent) untuk melakukan beberapa layanan atas nama mereka yang mendelegasikan sebagian kewenangan (principal) untuk membuat keputusan kepada agen. Pendelegasian wewenang pengambilan keputusan dari principal kepada agen biasanya diatur dalam suatu kontrak kerja yang berisi proporsi hak dan kewajiban masing-masing pihak dan diharapkan agen bertindak sesuai dengan kepentingan principal.

Eisenhardt (1989) menyatakan ada tiga asumsi sifat manusia terkait teori keagenan, yaitu: 1) manusia pada umumnya mementingkan diri sendiri (self interest), 2) manusia memiliki daya pikir terbatas mengenai persepsi masa mendatang (bounded rationality), dan 3) manusia selalu menghindari risiko (risk averse). Berdasarkan asumsi sifat dasar manusia tersebut manajer akan cenderung untuk bertindak oportunis, yaitu mengutamakan kepentingan pribadi, dimana hal ini akan memicu terjadinya konflik keagenan sehingga diperlukan peran pihak ketiga yang independen yaitu auditor untuk mengevaluasi pertanggungjawaban keuangan manajemen dan memberikan pendapat mengenai kewajaran laporan keuangan yang disajikan oleh manajemen.

Hubungan agensi muncul ketika satu orang atau lebih (principal) mempekerjakan orang lain (agent) untuk memberikan suatu jasa, kemudian mendelegasikan wewenang pengambilan keputusan kepada agen tersebut. Penyebab timbulnya masalah agensi ini yaitu adanya konflik kepentinga antara 
principal dan agent, akibat tidak bertemunya tujuan yang sejalan diantara mereka (Aurora, 2013).

Pada saat pemegang saham (principal) menunjuk manajer (agent) sebagai pengelola dan pengambil keputusan bagi perusahaan, pada saat itulah muncul hubungan keagenan antara pemegang saham dengan manajer. Manajer mengemban tanggung jawab moral untuk mengoptimalkan kepentingan pemegang saham (principal). Namun, di sisi lain manajer juga memiliki tujuan untuk memaksimumkan kesejahteraan dan kepentingannya sehingga terdapat kemungkinan agent tidak selalu bertindak untuk kepentingan terbaik principal (Jensen dan Meckling 1976)

Bukti teoritis mengenai pergantian auditor didasarkan pada teori agensi (Sulistiarini dan Sudarno, 2012:2). Baik principal maupun agent ingin mendapatkan keuntungan sebesar-besarnya serta ingin terhindar dari resiko yang mungkin terjadi dalam perusahaan. Dalam teori agensi, auditor independen berperan sebagai penengah kedua belah pihak (agent dan principal) yang berbeda kepentingan.

Auditor independen juga berfungsi untuk mengurangi biaya agensi yang timbul dari perilaku mementingkan diri sendiri yang dilakukan oleh manajer.

Auditing merupakan suatu proses sistematis untuk menghimpun dan mengevaluasi bukti-bukti secara obyektif mengenai asersi-asersi tentang berbagai tindakan dan kejadian ekonomi untuk menentukan tingkat kesesuaian antara asersiasersi tersebut dengan kreteria yang telah ditentukan dan menyampaikan hasilnya 
ISSN: 2302-8556

E-Jurnal Akuntansi Universitas Udayana

Vol.23.2. Mei (2018): 1332-1360

kepada para pemakai yang berkepentingan (Halim,2015:1).

Definisi auditing secara umum tersebut memiliki unsur-unsur penting yang diuraikan sebagai berikut (Halim,2015:1) merupakan suatu proses sistematis. Auditing merupakan rangkaian proses dan prosedur yang bersifat logis, terstruktur dan terorganisir. Untuk menghimpun dan mengevaluasi bukti secara objektif. Proses sistematis tersebut ditujukan untuk memperoleh bukti yang mendasari pernyataan yang dibuat oleh individu atau badan usaha, serta untuk mengevaluasi tanpa memihak atau berprasangka terhadap bukti-bukti tersebut. Asersi-asersi tentang berbagai tindakan dan kejadian ekonomi. Asersi atau pernyataan tentang tindakan dan kejadian ekonomi merupakan hasil proses akuntansi. Proses akuntansi ini menghasilkan suatu pernyataan yang disajikan dalam laporan keuangan. Menentukan tingkat kesesuaian. Pengumpulan bukti mengenai pernyataan dan evaluasi terhadap hasil pengumpulan bukti tersebut dimaksudkan untuk menetapkan kesesuaian pernyataan tersebut dengan kriteria yang telah ditetapkan. Tingkat kesesuaian antara pernyataan dengan kriteria tersebut kemungkinan dapat dikuantifikasikan, kemungkinan pula bersifat kualitatif. Kriteria yang telah ditetapkan. Kriteria atau standar yang dipakai sebagai dasar untuk menilai pernyataan dapat berupa peraturan yang ditetapkan oleh suatu badan legislatif, anggaran atau ukuran prestasi lain yang ditetapkan oleh manajemen, dan prinsip akuntansi berterima umum di Indonesia. Penyampaian hasil-hasilnya. Penyampaian hasil ini dilakukan secara tertulis dalam bentuk laporan audit (audit report). Pemakai yang berkepentingan. 
Dalam dunia bisnis, pemakai yang berkepentingan terhadap laporan audit adalah para pemakai informasi keuangan, seperti : pemegang saham, manajemen, kreditur, calon investor dan kreditur, organisasi buruh, dan kantor pelayanan pajak.

Menurut Arens dan Loebbecke (1992:1) auditing adalah proses yang ditempuh oleh seorang yang kompeten dan independen agar dapat menghimpun dan mengevaluasi bukti-bukti mengenai informasi yang terukur dari suatu entitas untuk mempertimbangkan dan melaporkan tingkat kesesuaian dari informasi yang terukur tersebut dengan kriteria yang telah ditetapkan

Audit yang dilakukan oleh auditor independen terhadap laporan keuangan suatu perusahaan memiliki suatu tujuan. SA Seksi 110 paragraf 01 menerangkan mengenai tujuan audit tersebut, dimana tujuannya adalah untuk menyatakan pendapat tentang kewajaran, dalam semua hal yang material, posisi keuangan, hasil usaha, perubahan ekuitas, dan arus kas sesuai dengan Standar Akuntansi Keuangan di Indonesia.Auditor switching adalah pergantian Kantor Akuntan Publik yang dilakukan oleh suatu perusahaan yang dapat terjadi karena peraturan pemerintah atau keinginan perusahaan itu sendiri. Menurut Wijayanti (2010), pergantian auditor secara wajib dengan secara sukarela dapat dibedakan atas dasar pihak mana yang menjadi fokus perhatian dari isu tersebut. Jika pergantian terjadi secara sukarela, maka fokus perhatian utama adalah pada sisi klien. Sebaliknya jika pergantian terjadi secara wajib, fokus perhatian utama beralih kepada auditor/KAP. 
ISSN: 2302-8556

E-Jurnal Akuntansi Universitas Udayana

Vol.23.2. Mei (2018): 1332-1360

Pada kondisi dimana tidak ada aturan yang mewajibkan pergantian auditor, terdapat dua kemungkinan yang akan terjadi ketika klien mengganti auditornya yaitu auditor mengundurkan diri atau auditor diberhentikan oleh klien. Apapun kemungkinan yang akan terjadi, perhatian utama tetap pada alasan apa saja yang mendasari terjadinya auditor switching tersebut dan kemana klien tersebut akan berpindah auditor (Widyanti, 2015). Sedangkan apabila pergantian auditor terjadi karena peraturan yang membatasi masa perikatan atau karena adanya ketidaksepakatan atas praktik akuntansi tertentu, maka perusahaan akan pindah ke auditor lain yang dapat bersepakat dengan perusahaan (Wijayanti, 2011).

Di Indonesia terdapat pembatasan jangka waktu untuk setiap Kantor Akuntan Publik (KAP) dan Akuntan publik (AP) dalam melakukan audit terhadap satu kliennya. Hal tersebut diatur dalam regulasi yang ditetapkan oleh pemerintah yang diatur dalam Peraturan Pemerintah No.20 tahun 2015 tentang Praktik Akuntan Publik yang menjelaskan bahwa pemberian jasa audit atas laporan keuangan historis terhadap suatu entitas oleh seorang Akuntan Publik dibatasi paling lama untuk 5 (lima) tahun buku berturut-turut (pasal 11 ayat 1) dan akuntan publik dapat memberikan kembali jasa audit atas informasi keuangan historis terhadap entitas setelah 2 (dua) tahun buku berturut-turut tidak memberikan jasa tersebut (pasal 11 ayat 4). Wibowo \& Rossieta (2009) mengungkapkan bahwa regulasi membatasi hal tersebut agar auditor dan klien tidak menciptakan suatu ketergantungan satu sama lain sehingga kualitas audit tetap terjaga.

Financial distress merupakan kondisi perusahaan yang sedang dalam 
keadaan kesulitan keuangan, artinya perusahaan berada dalam posisi yang tidak aman dari ancaman kebangkrutan atau kegagalan pada usaha perusahaaan tersebut. Financial distress bermula ketika suatu perusahaan tidak mampu memenuhi jadwal pembayaran atau ketika proyeksi arus kas menunjukkan bahwa dalam waktu dekat pembayaran itu tidak akan dapat dipenuhi (Sembiring, 2008).

Emrinaldi (2007) menyatakan kondisi yang paling mudah dilihat dari perusahaan yang mengalami financial disstres adalah pelanggaran komitmen pembayaran hutang diiringi dengan penghilangan pembayaran dividen terhadap investor.

Menurut Anggarini (2010) perusahaan yang mengalami financial distress akan menghadapi kondisi dimana tidak mampu memenuhi jadwal atau kegagalan pembayaran kembali hutang yang sudah jatuh tempo kepada kreditor, dan perusahaan dalam kondisi tidak solvable (insolvency).

Financial distress dapat timbul karena adanya pengaruh dari dalam perusahaan sendiri (internal) maupun dari luar perusahaan (eksternal). Sinaga (2012) mengutip Damodaran (2001) menyatakan bahwa faktor penyebab financial distress dari dalam perusahan adalah pertama kesulitan arus kas. Terjadi ketika penerimaan pendapatan perusahaan dari hasil operasi perusahaan tidak cukup untuk menutupi beban-beban usaha yang timbul atas aktivitas operasi perusahaan. Kesulitan arus kas juga disebabkan adanya kesalahan manajemen ketika mengelola aliran kas perusahan untuk membayaran aktivitas perusahaan yang memperburuk kondisi keuangan perusahaan. Kedua besarnya jumlah hutang. 
ISSN: 2302-8556

E-Jurnal Akuntansi Universitas Udayana

Vol.23.2. Mei (2018): 1332-1360

Kebijakan pengambilan hutang perusahaan untuk menutupi biaya yang timbul akibat operasi perusahaan akan menimbulkan kewajiban bagi perusahaan untuk mengembalikan hutang di masa depan. Ketika tagihan jatuh tempo dan perusahaan tidak mempunyai cukup dana untuk membayar tagihan-tagihan yang terjadi maka kemungkinan yang dilakukan kreditur adalah mengadakan penyitaan harta perusahaan untuk menutupi kekurangan pembayaran tagihan tersebut. Dan ketiga kerugian dalam kegiatan operasional perusahaan selama beberapa tahun. Kerugian operasional perusahaan menimbulkan arus kas negatif dalam perusahaan. Hal ini dapat terjadi karena beban operasional lebih besar dari pendapatan yang diterima perusahaan.

Perusahaan mampu menutupi atau menanggulangi tiga di atas, belum tentu perusahaan tersebut dapat terhindar dari financial distress. Karena masih terdapat faktor eksternal perusahaan yang menyebabkan financial distress. Faktor eksternal dapat berupa kebijakan pemerintah yang dapat menambah beban usaha yang di tanggung perusahaan, misalnya tarif pajak yang meningkat yang dapat menambah beban perusahaan. Selain itu masih ada kebijakan suku bunga pinjaman yang meingkat, menyebabkan beban bunga yang ditanggung perusahaan meningkat.

Reputasi auditor merupakan prestasi dan kepercayaan publik yang di sandang auditor atas nama besar yang dimiliki auditor tersebut (Rudyawan dan Badera, 2009). Reputasi auditor di Indonesia dikelompokkan menjadi 2 (dua) oleh IAI yaitu afiliasi dan non afiliasi. KAP yang berafiliasi dengan The Big Four dikatakan bereputasi dan 
KAP yang tidak berafiliasi dengan The Big Four dikatakan kurang bereputasi (Agiastuti dan Suputra,2016).

Klien biasanya mempersepsikan bahwa auditor yang berasal dari KAP besar dan berafiliasi dengan KAP internasional memiliki kualitas yang lebih tinggi karena auditor tersebut memiliki karakteristik yang dapat dikaitkan dengan kualitas seperti pelatihan, pengakuan internasional, serta adanya peer review (Crasswell,1998).

KAP yang besar dipersepsikan lebih memiliki reputasi yang baik dalam memelihara tingkat independensinya dibandingkan dengan KAP kecil karena KAP besar memberikan jasa pada banyak klien, dan hal itu yang mengurangi ketergantungan KAP besar pada klien tertentu (Susan dan Trisnawati,2011) mengutip Wilson dan Grimlund, 1990. Dan KAP Big Four dianggap memiliki kualitas yang lebih tinggi apabila dibandingkan dengan KAP non Big Four.

Financial distress merupakan tahap dimana kondisi keuangan perusahaan mengalami penurunan sebelum terjadinya kebangkrutan (Triwahyuningtias,2012). Auditor switching juga dapat disebabkan karena perusahaan tidak dapat memenuhi biaya audit yang dibebankan oleh KAP yang mengauditnya dikarenakan perusahaan sedang mengalami kondisi keuangan yang menurun (Sulistiarini dan Sudarno,2012). Biaya audit yang besar juga bisa mempengaruhi keputusan perusahaan untuk beralih ke KAP yang baru yang biaya auditnya lebih kecil (Wea dan Murdiawati, 2015).

Hudaib dan Cooke (2005) menyatakan perusahaan yang mengalami kesulitan keuangan lebih memilih untuk mengganti auditor dibandingkan perusahaan dalam 
ISSN: 2302-8556

E-Jurnal Akuntansi Universitas Udayana

Vol.23.2. Mei (2018): 1332-1360

kondisi keuangan yang sehat. Dimana financial distress dapat digunakan untuk memprediksi auditor switching yang dilakukan oleh perusahaan klien (Kwak et al.,2011)

Penelitian yang dilakukan oleh Nasser (2006), Sinarwati (2010), Chadegani (2011), dan Rahmawati (2011) juga mendapatkan hasil bahwa perusahaan yang mengalami financial disstress memiliki dorongan yang kuat untuk berpindah auditor daripada perusahaan yang tidak mengalami financial disstress. Berdasarkan uraian di atas maka dapat dirumuskan hipotesis penelitian sebagai berikut:

$\mathrm{H}_{1}$ : Financial disstress berpengaruh positif pada auditor switching

Perusahaan akan lebih memilih KAP dengan kualitas yang lebih baik untuk meningkatkan kualitas laporan keuangan dan reputasi perusahaan dimata pengguna laporan keuangan (Juliantari dan Rasmini,2013). Investor akan lebih cenderung pada data akuntansi yang dihasilkan dari auditor yang bereputasi (Praptotorini dan Januarti,2007). Perusahaan tidak akan mengganti KAP jika KAP-nya sudah bereputasi. Chadegani et al (2011) mengutip Hudaid and Cooke juga menyatakan bahwa perusahaan yang mengalami kesulitan keuangan cenderung untuk mengganti KAP mereka dibandingkan dengan perusahaan lain yang lebih sehat dengan alasan bahwa mereka perlu menyewa kualitas auditor yang lebih tinggi dibandingkan dengan sebelumnya untuk menarik kepercayaan stakeholders dan menambah kepercayaan diri perusahaan. Perusahaan yang mengalami kesulitan keuangan cenderung menggunakan auditor dengan independensi tinggi untuk mendapatkan kepercayaan pemegang saham, kreditur,dan mengurangi litigamasi (Nasser et 
al,2006). Menurut Schwartz dan Soo (1995) perusahaan yang bangkrut lebih sering berpindah auditor daripada perusahaan yang tidak bangkrut. Dengan mengganti auditornya dengan auditor yang lebih memiliki nama maka reputasi perusahaan juga akan terangkat di mata investor. Widyanti (2015) juga mengungkapkan bahwa perusahaan yang mengalami financial distress akan melakukan pergantian KAP dan memilih KAP yang bereputasi. Berdasarkan uraian diatas maka dapat dirumuskan hipotesis penelitian sebagai berikut:

$\mathrm{H}_{2}$ : Reputasi auditor memperkuat pengaruh financial disstress terhadap auditor switching

\section{METODE PENELITIAN}

Penelitian ini adalah penelitian kuantitatif dengan pendekatan asosiatif. Variabel yang digunakan dalam penelitian ini adalah Variabel Independen yaitu financial distress, Variabel Dependen adalah Auditor Switching, dan Variabel Moderasi adaldah Reputasi Auditor. Sampel yang digunakan dalam penelitian ini diambil dengan menggunakan metode purposive sampling, yaitu teknik pengambilan sampel dengan pertimbangan atau kreteria tertentu (Sugiyono, 2016:96). Kreteria yang dipertimbangkan dalam pengambilan sampel penelitian ini adalah sebagai berikut: perusahaan sudah terdaftar di Bursa Efek Indonesia sebelum 1 Januari 2012, perusahaan terdaftar secara berturut-turut selama periode penelitian,yaitu 2012-2016, perusahaan tidak delisting selama periode penelitian 2012-2016, perusahaan melakukan pergantian KAP selama periode penelitian, perusahaan tidak melakukan pergantian KAP secara mandatory selama periode penelitian. 
ISSN: 2302-8556

E-Jurnal Akuntansi Universitas Udayana

Vol.23.2. Mei (2018): 1332-1360

Teknik analisis yang digunakan adalah regresi logistik. Analisi regresi logistik adalah suatu bentuk analisis khusus yang dimana variabel terikatnya bersifat kategori dan variabel bebasnya bersifat kategori dan kontinu dari keduanya. Analisis regresi logistik tidak perlu menguji asumsi normalitas data pada variabel bebasnya karena variabel bebas merupakan campuran antara variabel kontinu dan kategori (Ghozali,2011).

\section{HASIL DAN PEMBAHASAN}

Statistik deskriptif memberikan gambaran atau deskripsi mengenai setiap variabel yang menunjukkan nilai rata-rata (mean), standar deviasi, varian, nilai minimum, dan nilai maksimum. Hasil pengujian statistik deskriptif disajikan dalam Tabel 1 berikut.

Tabel 1.

Hasil analisis statistik deskriptif

\begin{tabular}{llllll}
\hline & N & Minimum & Maksimum & Mean & Std. Deviation \\
\hline $\begin{array}{l}\text { Financial distress } \\
\text { Reputasi }\end{array}$ & 55 & 0,03 & 5,30 & 0,9200 & 1,00349 \\
Auditor switching & 55 & 0 & 1 & & \\
& 55 & 0 & 1 & 0,0909 & 0,29013 \\
& & & & 0,2909 & 0,45837 \\
\hline
\end{tabular}

Sumber: Data diolah,2017

Berdasarkan Tabel 1 dapat dijelaskan hasil sebagai berikut: variabel financial distress memiliki nilai minimum sebesar 0,03; nilai maksimum 5,30; mean sebesar 0,9200 dan standar deviasi sebesar 1,00349. Nilai mean sebesar 0,9200 menunjukkan bahwa terdapat lebih banyak perusahaan yang mengalami financial distress.

Variabel reputasi auditor memiliki nilai minimum sebesar 0; nilai maksimum sebesar 1; mean sebesar 0,0909 dan standar deviasi sebesar 0,29013. Nilai mean sebesar 0,0909 menunjukkan bahwa terdapat lebih banyak perusahaan yang tidak menggunakan KAP yang berafiliasi dengan Big Four. 
Variabel auditor switching memiliki nilai minimum sebesar 0; nilai maksimum sebesar 1; mean sebesar 0,2909 dan standar deviasi sebesar 0,45837. Nilai mean sebesar 0,2909 menunjukkan bahwa terdapat lebih banyak perusahaan yang tidak melakukan auditor switching.

Analisis data dalam penelitian ini dilakukan dengan menggunakan regresi logistik karena variabel dependen bersifat dikotomi yaitu melakukan pergantian KAP dan tidak melakukan pergantian KAP. Regresi logistik digunakan untuk menguji apakah probabilitas terjadinya variabel terikat dapat diprediksi dengan variabel bebasnya (Ghozali, 2011). Teknik analisis regresi logistik tidak memerlukan asumsi normalitas data pada variabel bebasnya (Ghozali, 2011) dan mengabaikan heteroskedastisitas (Gujarati,2003).

Pengujian ini dilakukan untuk menguji hipotesis nol bahwa data emperis cocok atau sesuai dengan model. Kelayakan model refresi dinilai dengan menggunakan uji Hosmer and Lemeshow's Goodness of Fit Test. Jika nilai statistik uji Hosmer and Lemeshow's Goodness of Fit Test lebih besar dari 0.05 maka hipotesis nol diterima dan berarti model mampu memprediksi nilai observasinya atau dapat dikatakan model dapat diterima karena cocok dengan data observasinya. Berikut ini disajikan tabel uji Hosmer and Lemeshow's Goodness of Fit Test.

Tabel 2.

Hasil uji menilai kelayakan model regresi

\begin{tabular}{cccc}
\hline Step & Chi-Square & df & Sig. \\
\hline 1 & 11.821 & 7 & .107 \\
\hline Sumber: Data diolah,2017 & & &
\end{tabular}


ISSN: 2302-8556

E-Jurnal Akuntansi Universitas Udayana

Vol.23.2. Mei (2018): 1332-1360

Tabel uji Hosmer and Lemeshow di atas dapat dilihat bahwa nilai signifikansi uji Hosmer and Lemeshow yaitu sebesar 0,107 yang lebih besar dari 0,05 maka hipotesis nol diterima dan berarti model mampu memprediksi nilai observasinya atau dapat dikatakan model dapat diterima karena cocok dengan data observasinya.

Pengujian ini dilakukan untuk mengetahui apakah keseluruhan model sesuai dengan data. Pengujian dilakukan dengan membandingkan nilai antara -2 Log Likelihood (-2LL) pada awal (Block Number $=0$ ) dengan nilai -2 Log Likehood (2LL) pada akhir (Block Number $=1$ ). Apabila terdapat penurunan nilai Likehood, ini menunjukkan model regresi yang baik atau dengan kata lain model yang dihipotesiskan fit dengan data. Hasil pengujian ditampilkan dalam tabel 3 berikut.

Tabel 3.

Perbandingan -2Log Likelihood Awal dan Akhir

\begin{tabular}{lc}
\hline -2LL awal (Block Number $=0$ ) & 66,360 \\
\hline -2LL akhir (Block Number $=$ 1) & 46,654 \\
\hline
\end{tabular}

Sumber: Data diolah,2017

Nilai -2LL awal sebesar 66,360 dan nilai -2LL akhir sebesar 46,654. Penurunan nilai -2LL ini menunjukkan bahwa model regresi yang baik atau dengan kata lain model yang dihipotesiskan fit dengan data.

Besarnya nilai koefisien determinasi pada model regresi logistik ditunjukkan dengan nilai Nagelkerke's $R$ Square. Nilai Nagelkerke's $R$ Square adalah variabilitas variabel tetap yang dapat dijelaskan oleh variabel bebas, sedangkan sisanya dijelaskan oleh variabel-variabel lain diluar penelitian. Nagelkerke's $R$ Square ini 
digunakan untuk mengukur seberapa besar variabel bebas yang digunakan dalam penelitian ini yaitu financial distress mampu mempengaruhi variabel terikat auditor switching. Berikut hasil pengujian pada Tabel 4.

Tabel 4. Model Summary

\begin{tabular}{cccc} 
Step & $\mathbf{- 2}$ Log Likelihood & $\begin{array}{c}\text { Cox \& Snell R } \\
\text { Square }\end{array}$ & $\begin{array}{c}\text { Nagelkerke R } \\
\text { Squar }\end{array}$ \\
\hline 1 & 46,654 & 0,301 & 0,429
\end{tabular}

Sumber: Data diolah,2017

Berdasarkan Tabel 4 menunjukkan bahwa nilai Nagelkerke's $R$ Square sebesar 0,429. Hal ini berarti variabel bebas yaitu financial distress serta variabel moderasi yaitu reputasi auditor yang digunakan dalam penelitian ini mampu menjelaskan variabilitas variabel terikat auditor switching sebesar $42,9 \%$ sedangkan $57,1 \%$ dijelaskan oleh variabel lain yang tidak dimasukkan dalam penelitian ini.

Matriks klasifikasi menunjukkan kekuatan prediksi dari model regresi untuk memprediksi kemungkinan perusahaan melakukan auditor switching. Hasil pengujian ditampilkan dalam tabel 5 berikut.

Tabel 5. Matriks Klasifikasi

\begin{tabular}{ccccccc}
\hline & Observed & & Y & Predicted & Percentage \\
& & & & & Correct \\
\hline Step 1. & Y & .00 & 38 & & 1.00 & 97.4 \\
& & 1.00 & 9 & 7 & 43.8 \\
\multicolumn{2}{c}{ Overall Percentage } & & & & 81.8 \\
\hline
\end{tabular}

Sumber: Data diolah,2017 
ISSN: 2302-8556

E-Jurnal Akuntansi Universitas Udayana

Vol.23.2. Mei (2018): 1332-1360

Hasil pengujian menunjukkan kekuatan prediksi dari model regresi untuk memprediksi kemungkinan perusahaan melakukan auditor switching adalah sebesar 81,8 persen. Hal ini menunjukkan bahwa dengan model regresi tersebut, terdapat sebanyak 38 perusahaan tidak melakukan pergantian KAP dan 9 perusahaan melakukan pergantian KAP. Berdasarkan hasil analisis dengan menggunakan program SPSS maka diperoleh hasil sebagai berikut:

Tabel 6.

Variables in the Equation

\begin{tabular}{cccccccc}
\hline & & B & S.E. & Wald & df & Sig. & $\operatorname{Exp(B)}$ \\
\hline Step & $\mathrm{X} 1$ & .969 & .430 & 5.067 & 1 & .024 & 2.634 \\
1 & $\mathrm{X} 2$ & 23.438 & 21757.997 & .000 & 1 & .999 & $2 \mathrm{E}+010$ \\
& $\mathrm{x} 1 \mathrm{x} 2$ & -.969 & 9041.534 & .000 & 1 & 1.000 & .380 \\
& Constant & -2.235 & .582 & 14.729 & 1 & .000 & .107 \\
\hline
\end{tabular}

Sumber: Data diolah,2017

Berdasarkan Tabel 6 diperoleh persamaan regresi sebagai berikut:

$\operatorname{Ln} \frac{A S}{1-A S}=-2,235+0,969 \mathrm{X}+23,438 \mathrm{Z}-0,969 \mathrm{XZ}+\varepsilon$

Berdasarkan model regresi logistik yang terbentuk, dapat diinterpretasikan hasil sebagai berikut. Nilai konstanta sebesar -2,235 mempunyai arti bahwa jika tidak terjadi financial distress dan reputasi auditor maka kecendrungan tidak akan terjadi auditor switching. Persamaan koefisien regresi logistik dari financial distress sebesar 0,969 mempunyai arti bahwa apabila financial distress naik, maka auditor switching akan cenderung mengalami peningkatan dengan asumsi faktor lainnya konstan.

Persamaan koefisien regresi logistik dari reputasi auditor sebesar 23,438 mempunyai arti bahwa apabila reputasi auditor naik, maka auditor switching akan cenderung mengalami peningkatan dengan asumsi faktor lainnya konstan. Persamaan 
koefisien regresi dari interaksi antara financial distress dengan reputasi auditor menunjukkan nilai koefisien bernilai negatif sebesar 0,969. Hasil tersebut mempunyai arti bahwa apabila reputasi auditor cenderung meningkat, maka akan memperlemah pengaruh financial distress pada kecendrungan perusahaan melakukan auditor switching dengan asumsi faktor lainnya konstan.

Hipotesis pertama menyatakan bahwa financial distress berpengaruh positif pada auditor switching. Berdasarkan Tabel 6 variabel financial distress menunjukkan nilai koefisien positif sebesar 0,969 dengan signifikansi 0,024 lebih kecil dari 0,05. Hal ini berarti hipotesis pertama diterima yang artinya financial distress berpengaruh positif pada auditor switching.

Hipotesis kedua menyatakan bahwa reputasi auditor memoderasi pengaruh financial distress terhadap auditor switching. Berdasarkan Tabel 6 variabel financial distress diinteraksikan dengan reputasi auditor menunjukkan nilai koefisien negatif sebesar 0,969 yang memiliki arti bahwa dengan adanya reputasi auditor maka akan memperlemah pengaruh financial distress pada auditor switching dengan signifikansi 1,000 lebih besar dari 0,05 . Hal ini berarti hipotesis kedua ditolak, yang artinya reputasi auditor tidak mampu memoderasi pengaruh financial distress pada auditor switching.

Hasil pengujian dengan menggunakan regresi logistik menunjukkan nilai koefisien positif sebesar 0,969 dengan tingkat signifikansi 0,024 yang lebih kecil dari $\alpha=5 \%(0,024<0,05)$. Hal ini diinterpretasikan bahwa variabel financial distress berpengaruh positif pada auditor switching. Ketika perusahaan sedang mengalami 
ISSN: 2302-8556

E-Jurnal Akuntansi Universitas Udayana

Vol.23.2. Mei (2018): 1332-1360

kesulitan keuangan maka akan meningkatkan kemungkinan perusahaan untuk melakukan auditor switching. Hasil penelitian ini sejalan dengan penelitian yang dilakukan oleh Nasser (2006), Sinarwati (2010), Chadegani (2011), dan Rahmawati (2011) yang mendapatkan hasil bahwa perusahaan yang mengalami financial disstress memiliki dorongan yang kuat untuk berpindah auditor daripada perusahaan yang tidak mengalami financial disstress.

Hasil uji regresi logistik menunjukkan nilai koefisien negatif sebesar 0,969 dengan tingkat signifikansi sebesar 1,000 yang lebih besar dari $\alpha=5 \%(1,000>$ 0,05). Berdasarkan hasil pengujian ini menunjukkan bahwa variabel reputasi auditor tidak mampu memoderasi pengaruh financial distress pada auditor switching. Hasil penelitian ini menunjukkna bahwa reputasi auditor tidak menyebabkan perusahaan yang sedang mengalami kesulitan keuangan untuk mengganti auditornya. Dalam penelitian ini, perusahaan yang telah menggunakan KAP yang bereputasi, ketika melakukan pergantian KAP masih tetap menggunakan KAP yang bereputasi (berafiliasi dengan Big four). Kondisi dimana perusahaan tidak dapat membayar KAP besar dan mengganti dengan KAP yang lebih kecil memiliki tujuan untuk mengurangi fee audit, karena perusahaan mengalami kesulitan keuangan. Perusahaan juga dapat menambah modalnya agar kondisi perusahaan menjadi baik.

\section{SIMPULAN}

Berdasarkan hasil analisis data dan pembahasan pada bab sebelumnya, maka dapat ditarik kesimpulan sebagai berikut: 1). Financial distress berpengaruh positif pada kecendrungan perusahaan melakukan auditor switching secara voluntary pada 
perusahaan property \& real estate yang terdaftar di BEI tahun 2012-2016. Hasil penelitian menunjukkan bahwa financial distress merupakan faktor pendorong bagi perusahaan untuk mengganti KAP yang lama dengan KAP yang baru; 2). Reputasi auditor tidak mampu memoderasi pengaruh financial distress pada auditor switching, dengan demikian hipotesis kedua $\left(\mathrm{H}_{2}\right)$ di tolak.

Berdasarkan hasil penelitian dan simpulan di atas, adapun saran untuk penelitian selanjutnya dan untuk pihak-pihak yang berkepentingan sebagai berikut, penelitian ini menunjukkan nilai R Square sebesar 0,429 yang berarti variabel bebas yang digunakan dalam penelitian ini mempengaruhi variabel terikat sebesar $42,9 \%$, sedangkan sisanya sebesar $57,1 \%$ di pengaruhi oleh variabel lain. Penelitian selanjutnya dapat menambahkan variabel lain untuk memprediksi auditor switching. Penggunaan jenis industri yang lain juga dapat dilakukan guna memperoleh perbandingan antara tiap jenis industri yang berbeda.

\section{REFERENSI}

Agiastuti, Ida Ayu Putu dan I Dewa Gede Dharma Suputra. 2016. Faktor-faktor yang Berpengaruh pada Voluntary Auditor switching. Dalam E-Jurnal Akuntansi Universitas Udayana, (17)1.

Anggarini, T.V. 2010. Pengaruh Karakteriktik Komite Audit Terhadap Financial distress. Skripsi. Program Sarjana Universitas Diponegoro. Semarang.

Arsani. 2011. Analisis Ketepatan Model Prediksi Financial distress Perusahaan Manufaktur yang Terdaftar Di Bursa Efek Indonesia. Tesis Fakultas Ekonomi Univestitas Udayana, Denpasar.

Arens, Alvin A and Loebbecke James. 1992. Auditing: Suatu Pendekatan Terpadu. Jakarta: Erlangga.

Arestantya, Ida Ayu Radha. 2016. Ukuran Kantor Akuntan Publik sebagai 
ISSN: 2302-8556

E-Jurnal Akuntansi Universitas Udayana

Vol.23.2. Mei (2018): 1332-1360

Pemoderasi Pengaruh Auditor switching pada Kualitas Audit. Skripsi Fakultas Ekonomi dan Bisnis Universitas Udayana,Denpasar.

Blouin, J., Grein, B.M., and Rountree, B.R. 2007. An Analysis of Forced Auditor Change: The Case of Former Arthur Andersen Clients. The Accounting Review. 82:h:621-650.

Chadegani, Arezoo Aghaeni., Zakiah Muhammadun Mohamed and Azam Jari. 2011. The Determinant Factors of Auditor Switch Among Companies Listed on Tehran Stock Exchange. International Conference on Sociality and Economics Development IPEDR 10

Crasswell, AT. 1998. The Association Between Quailed Opinions and Auditor Switches. Accounting and Bussiness Research, 19 ${ }^{\text {th }}$, pp:23-31.

Eisenhardt, Kathleem. 1989. Agency Theory: An Assesment and Review. Academy of Management Review, 14 :h: 57-74.

Emrinaldi. 2007. Analisis Pengaruh Praktek Tata Kelola Perusahaan (Corporate Governance) Terhadap Kesulitan Keuangan Perusahaan (Financial distress): Suatu Kajian Emperis. Jurnal Bisnis Dan Akuntansi, 9(1),pp:71-86.

Ghozali, Imam. 2013. Aplikasi Analisis Multivariate Dengan Program IBM SPSS 21. Semarang: Penerbit Universitas Diponegoro.

Gholizadeh, Mohammad Hasan, Mohsen Mohammad, Ali Bahmani and Behnam Shadi Dizaji. 2011. Corporate Financial distress Prediction Using Artificial Neurat Networks and Using Micro-Level Financial Indicators. Interdisciplinary Journal of Contemporary Research In Business, 3(5).

Halim, Abdul. 2015. Auditing (Dasar-dasar Audit Laporan Keuangan) Jilid 1. Edisi Kelima. Yogyakarta: UPP STIM YKPN.

Hudaib M, and TE Cooke. 2005. Qualified Audit Opinion and Auditor switching. Department of Accounting and Finance School of Business and Economics University of Exeter Streathem Court, UK.

Institut Akuntan Publik Indonesia. 2011. Standar Profesional Akuntan Publik. Jakarta: Salemba Empat.

Indriantoro, N. dan Sopomo, B. 2013. Metodologi Penelitian Bisnis Untuk Akuntansi dan Manajemen. Yogyakarta: Fakultas Ekonomika dan Bisnis UGM. 
Jensen, M.C and W.H. Meckling. 1976. Theory of the Firm: Managerial Behavior, Agency Costs and Ownership Structure. Journal of Financial Economics 3,h:305-360.

Juliantari,Ni Wayan Ari dan Ni Ketut Rasmini. 2013. Auditor Switching dan FaktorFaktor yang Mempengaruhinya. E-Jurnal Akuntansi Universitas Udayana 3(3),pp:231-246.

Khasharmeh,Hussein Ali. 2015. Determinants of Auditor Switching in Bahraini's Listed Companies an Empirical Study. European Journal of Accounting and Finance Research 3(11):pp:73-99.

Kieso E, Donald, Jerry J, Weygandt and Teery D. Warfield, 2007. Accounting Principles, Edisi 12 by: Salemba Empat.

Kwak, Wikil, Susan Eldridge, Yong Shi and Gang Kou. 2011. Predicting Auditor Change Using Financial Distress Variables and The Multiple Criteria Linear Programming (MCPL) and Other Mining Approach (Comparation). The Journal of Applied Business Research, 7(6).

Mahantara, A.A. Gede Widya. 2013. Faktor-Faktor yang Memengaruhi Pergantian Kantor Akuntan Publik pada Perusahaan yang Terdaftar di Bursa Efek Indonesia. Tesis. Program Pascasarjana, Universitas Udayana.

Meutia, Intan. 2004. Pengaruh Independensi Auditor Terhadap Manajemen Laba untuk KAP Big 5 dan Non Big 5. Jurnal Riset Akuntansi Indonesia, 7(3), $\mathrm{h}: 333-350$.

Nabila. 2011. Faktor-Faktor yang Mempengaruhi Auditor switching (Studi Empiris pada Perusahaan Manufaktur di Bursa Efek Indonesia). Skripsi. Fakultas Ekonomi, Universitas Diponogoro.

Nasser, et al. 2006. Auditor Client Relationship: The Case of Audit Tenure and Auditor switching in Malaysia. Managerial Auditing Journal, 21 (7), pp: 724-737.

Pradnyana, Made Aditya Bayu dan I.D.G. Dharma Suputra. 2015. Pengaruh Audit Fee, Going Concern, Financial distress, Ukuran Perusahaan, Pergantian Manajemen pada Pergantian Auditor. E-Jurnal Akuntansi Universitas Udayana 11(3), pp: 713-729. 
ISSN: 2302-8556

E-Jurnal Akuntansi Universitas Udayana

Vol.23.2. Mei (2018): 1332-1360

Praptitorini, MD. Dan Januarti I. 2007. Analisis Pengaruh Kualitas Audit, Debt Default dan Opinion Shopping terhadap Penerimaan Opini Going Concern. Naskah Lengkap Simposium Nasional Akuntansi X. Makassar.

Pratitis, Yanwar Titi. 2012. Auditor switching : Analisis Berdasarkan Ukuran KAP, Ukuran Klien dan Financial distress. Accounting Analysis Journal,1 (1):h:27-32.

Putra, I Gusti Bayu Pratama. 2015. Pengaruh Opini Audit dan Reputasi KAP pada Auditor switching dengan Financial distress sebagai Variabel Moderasi. Skripsi. Universitas Udayana.

Rahayu, Santi. 2012. Moderasi Reputasi Auditor terhadap Faktor-faktor yang Mempengaruhi Auditor switching pada Perusahaan Industry Manufaktur yang Terdaftar di Bursa Efek Indonesia pada Tahun 2006-2010. Tesis Universitas Esa Unggul. Jakarta.

Rudyawan, Arry Pratama dan I Dewa Nyoman Badera. 2009. Opini Audit Going Concern Kajian Berdasarkan Model Prediksi Kebangkrutan, Pertumbuhan Perusahaan, Leverage, Dan Reputasi Auditor. Jurnal Akuntansi dan Bisnis, 4(2).

Rossieta,Hilda dan Arie Wibowo. 2009. Faktor-faktor Determinasi Kualitas AuditSuatu Study dengan pendekatan Earnings Suprise Benchmark. Simposium Nasional Akuntansi XII, Palembang, h:1-34.

Saheli,Mahdi dan Bizhan Abedini.2009. Financial Distress Prediction in Emerging Market Emperical Evidences from Iran. Business Intelligence Journal,2(2).

Schwartz,K.B. dan B.S. Soo. 1995. An Analysis of Firm 8-K Disclousure of Auditor Changes by Firms Approaching Bankruptcy, Auditing: A Journal of Practice Theory, 14 (1):h:125-135.

Sembiring, Seniwati. 2008. Pengaruh Ukuran Perusahaan dan Kebijakan Pendanaan Terhadap Kinerja Keuangan pada Perusahaan Bisnis Property di Bursa Efek Jakarta. Tesis Program Studi Ilmu Ekonomi Pascasarjana Universitas Sumatera Utara. Medan.

Sinaga, Daud M.T., 2012. Analisis Pengaruh Audit Tenure, Ukuran Kap dan Ukuran Perusahaan Klien terhadap Kualitas Audit. Skripsi. Universitas Diponogoro Semarang. 
Sinarwati, Kadek. 2010. Mengapa Perusahaan Manufaktur yang Terdaftar di BEI Melakukan Pergantian Kantor Akuntan Publik. Simposium Nasional Akuntansi XIII.Purwakerto.

Singgih, Elisha Muliani dan Icuk Ranggak Bawono. 2010. Pengaruh independensi, pengalaman, Due Proffesional Care dan Akuntabilitas terhadap Kualitas Audit. Simposium Nasional Akuntansi XIII, Purwekerto.

Siregar,Sylvia Veronika, Fitriany Amarullah, Arie Wibowo and Viska Anggraita. 2012. Audit Tenure, Auditor Rotation and Audit Quality: The Case of Indonesia. Asian Journal of Business and Accounting, 5(1), pp:55-74.

Sugiyono, 2013. Metode Penelitian Pendidikan (Pendekatan Kuantitatif, Kualitatif dan $R \& D$. Bandung: Alfabeta

Sugiyono. 2016. Metode penelitian Administrasi. Cetakan ke 23. Bandung: Alfabeta.

Sulistiarini, Endina dan Sudarno. 2012. Analisis Faktor-faktor Pergantian Antar Akuntan Publik. Diponegoro Journal of Accounting,1(2):h:1-12.

Suparlan dan Wuryan Andayani. 2010. Analisis Emperis Pergantian Kantor Akuntan Publik Setelah Ada Kewajiban Rotasi Audit. Simposium National Akuntansi XIII. Purwekerto.

Suroso, 2006. Investasi pada Saham Perusahaan yang Menghadapi Financial distress, Usahawan. No.2. Tahun XXXV

Susan dan Estralita Trisnawati. 2011. Faktor-Faktor yang Mempengaruhi Perusahaan Melakukan Auditor Switch. Jurnal Bisnis dan Akuntansi, 13(2):h: 131-144.

Wea,Alexandros Ngala Solo dan Dewi Murdiawati. 2015. Faktor-faktor yang Mempengaruhi Auditor switching Secara Voluntary pada Perusahaan Manufaktur. Dalam Jurnal Bisnis dan Ekonomi(JBE), 22(2):h:154-170.

Widyanti,A.A. Sagung Istri Agung. 2015. Reputasi Auditor Sebagai Pemoderasi Pengaruh Financial distress pada Auditor switching. Skripsi. Universitas Udayana. Denpasar.

Wijayanti, Evi dan Januarti. 2011. Analisis Faktor-faktor yang Mempengaruhi Perusahaan di Indonesia Melakukan Auditor switching. Simposium Nasional Akuntansi XIV. Aceh. 
ISSN: 2302-8556

E-Jurnal Akuntansi Universitas Udayana

Vol.23.2. Mei (2018): 1332-1360

Wijayanti, Martina Putri. 2010. Analisis Hubungan Auditor-Klien: Faktor-faktor yang Mempengaruhi Auditor switching di Indonesia. Skripsi Universitas Diponegoro. Semarang.

Menteri Keuangan, 2008, Peraturan Menteri Republik Indonesia Nomor 17/PMK.01/2008 tentang “Jasa Akuntan Publik",Jakarta.

Peraturan Pemerintah Republik Indonesia Nomor 20 Tahun 2015 tentang Praktik Akuntan Publik.

Undang-Undang Republik Indonesia Nomor 5 Tahun 2011 tentang Akuntan Publik. 